
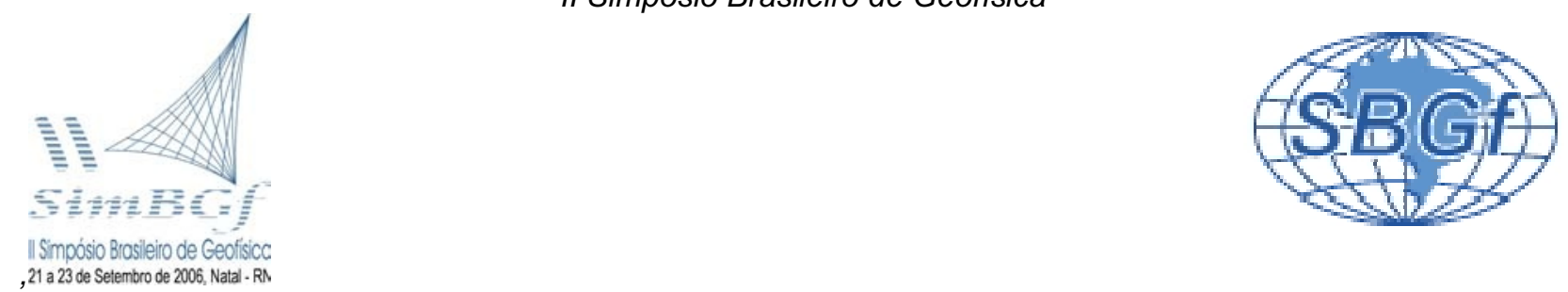

\title{
Estimativas do Fluxo Geotérmico e Calor Radiogênico na porção sul do Craton São Francisco
}

Carlos H. Alexandrino e Valiya M. Hamza, Ob servatório Nacional - ON/MCT, Rio de Janeiro.

Copyright 2006, SBGf-Sociedade Brasileira de Geofísica

Este texto foi preparado para a apresentação no II Simpósio de Geofísica da Sociedade Brasileira de Geofísica, Natal, 21-23 de setembro de 2006. Seu conteúdo foi revisado pela Comissão Tecno-cientifica do II SR-SBGfmas não necessariamente representa a opinião da SBGfou de seus associados. E proibida a reprodução total ou parcial deste material para propósitos comerciais sem prévia autorização da SBGf.

\section{Resumo}

Apresenta-se neste trabalho resultados de estudos geotérmicos recentes realizados no segmento sul do Craton São Francisco. Os valores médios de fluxo geotérmico encontrados na província de Tocantins e na área de Triângulo Mineiro são maiores em relação àqueles das províncias de Mantiqueira e da Bacia de São Francisco. Estimativas de calor radiogênico das camadas profundas da crosta foram obtidas com base em dados de velocidades das ondas sísmicas. Os resultados indicam que $o$ calor radiogênico diminui com a profundidade, sendo que o parâmetro de decréscimo linear está no intervalo de $10-20 \mathrm{~km}$.

Temperaturas da crosta foram calculadas para as quatro províncias tectônicas. Os modelos utilizados levam em consideração a variação da condutividade térmica com a temperatura. Os resultados indicam que os contrastes de temperatura, entre as províncias, alcançam valores de ordem de $500^{\circ} \mathrm{C}$, na base da crosta. Há indícios de que esta diferença de temperatura é o fator principal que determina padrões de dobramentos em processos metamórficos regionais.

\section{Introdução}

Os estudos geotérmicos realizados nas décadas anteriores na área cratônica da São Francisco tiveram como enfoque a aquisição experimental de dados de parâmetros básicos. Foram determinados valores de gradiente geotérmico e de condutividade térmica que permitiram determinações de fluxo geotérmico em cerca de dez localidades. A baixa densidade de dados não permitiram mapeamento do fluxo geotérmico em escala regional e estudos complementares sobre campo térmico da crosta.

A fim de superar essas dificuldades foi iniciado nos últimos anos um projeto de pesquisa no Laboratório de Geotermia do Observatório Nacional - ON/MCT visando aquisição de dados geotérmicos complementares e modelagem do campo térmico da crosta cratônica e das áreas vizinhas. Apresentam-se neste trabalho os resultados obtidos nas fases inicias deste projeto.

\section{Contexto Geológico}

O segmento sul do Craton São Francisco apresenta algumas das estruturas geológicas mais antigas do território brasileiro, caracterizadas por idades que variam de Arqueano ao Fanerozóico. De acordo com os estudos geológicos realizados nas últimas décadas (Almeida et al, 1977, 1981; Saadi, 1991; entre outros) foram identificadas diversas províncias geotectônicas na área de estudo, sendo que as principais são a Mantiqueira (na parte leste), Tocantins (na parte oeste), e a Bacia de São Francisco (na parte centro-norte). Ocorre se ainda, na região de Triangulo Mineiro as unidades tectônicas pertencentes à Bacia do Paraná.

$\mathrm{Na}$ análise de questões relacionadas com o campo térmico crustal, é importante salientar que os vestígios das perturbações térmicas dos processos geológicos anterior ao período Mesozóico são praticamente desprezíveis no campo térmico atual. Esta observação é baseada em estimativas de constante de tempo da litosfera em questão. Desta forma, detalhes de processos térmicos que ocorreram nas fases de cratonização e na formação das províncias tectônicas de Mantiqueira, Tocantins e Bacia São Francisco não possuem relevância direta para estudos do campo térmico atual. Restam-se apenas efeitos de calor residual gerada por intrusivas magmáticas alcalinas do período Cenozóico.

\section{Dados de Fluxo Geotérmico}

Nas fases iniciais deste trabalho foram efetuadas compilações de dados geotérmicos constantes nos estudos anteriores e aquisição de dados complementares. Foram consultados os trabalhos de Hamza et al (1978), Vitorello et al (1978), Eston et al (1981), Araújo (1980), Hamza (1982) e Hurter et al (1987). Contudo, os dados constantes desses trabalhos anteriores possuem qualidades variáveis, o que dificulta análise integrada dos resultados. Desta forma, decidiu-se pelo agrupamento dos resultados em três classes distintas:

- Determinações diretas de gradiente e medições de condutividade térmica visando determinação de fluxo de calor pelo método convencional (CVL);

- Estimativas de fluxo de calor com base em dados físicoquímicos das fontes termais, pelo método denominado geoquímico (GCL);

- Determinações experimentais de gradiente térmico, com base em perfis térmicos de poços de água subterrânea, pelo método de temperatura do findo do poço (CBT). 